\title{
Haze Particles for Removal of Multiple Heavy Metals from Wastewater
}

\author{
Tingyi Liu ${ }^{1}$, Yanqiu Sun ${ }^{1}$ and Zhong-Liang Wang ${ }^{1,2, \text { * }}$ \\ ${ }^{1}$ Tianjin Key Laboratory of Water Resources and Environment, Tianjin Normal University, Tianjin 300387, China \\ ${ }^{2}$ State Key Laboratory of Environmental Geochemistry, Institute of Geochemistry, Chinese Academy of Sciences, Guiyang 550002, China
}

\begin{abstract}
Haze has been a worldwide problem disturbing the daily life of human, and even causing a variety risk to human health. However, haze particles, normally named "air pollutants" and "toxic wastes", were firstly used to remove heavy metals from wastewater with a high efficiency. The morphology of haze particles with a mean diameter of $5.2 \mu \mathrm{m}$ and predominant anions on the surface were heterogeneous and uneven, which is favorable for adsorbing heavy metals. Environmental factors played an important role in the removal rates and $K_{o b s}$ of heavy metals. The removal of $\mathrm{Cr}$ (VI), Cd (II) and $\mathrm{Pb}$ (II) by haze particles could be well described by pseudo-first-order kinetic model. Heavy metals were removed in the order $\mathrm{Pb}$ (II) $>\mathrm{Cd}$ (II) $>\mathrm{Cr}$ (VI). X-ray photoelectron spectroscope (XPS) results indicated that the removal mechanism of $\mathrm{Cr}(\mathrm{VI}), \mathrm{Pb}$ (II) and $\mathrm{Cd}$ (II) by haze particles was a physical adsorption process, leading to an occurrence of the regeneration, especially for cationic ions. This study demonstrated the potential application of haze particles as effective remediation materials for heavy metals contamination, as well as contributing to utilizing waste materials and protecting the environment for sustainable development.
\end{abstract}

\section{Introduction}

In recent years, air pollution accidents have been reported frequently in China [1]. From then on, great efforts have been made to improve the air quality [2]. However, air pollution has been a major concern to environmental safety and public health because of its serious effect on human daily life [3]. Haze was defined as one kind of the air pollution with a high concentration of fine particles that led to a relative humidity lower than $90 \%$ at a visibility of less than $10 \mathrm{~km}[4,5]$. Haze particles were uniformity of size grading ranging from $0.001 \mu \mathrm{m}$ to 10 $\mu \mathrm{m}$, the most commonly named $\mathrm{PM}_{2.5}$ and $\mathrm{PM}_{10}$. Haze could not only decrease air quality and endanger public health, but also alter the hydrological cycle and even cause climate change [6].

A lot of studies have focused on characteristics, distribution, sources and transformation process of haze during atmospheric transport [3, 7-10]. Coal burning, iron and steel industry and vehicle emission were important sources in China [9]. Agricultural biomass burning in northern China contributed significantly to the regional haze between 12 and 20 June and the diameter of the dominant particle types in the fine fraction was less than $1 \mu \mathrm{m}$ [11]. High concentrations of water-soluble ions, carbonaceous species and heavy metals were found in both fine and coarse particles in haze [2]. Especially, heavy metal bonded $\mathrm{PM}_{2.5}$ was left to suspend in the atmosphere for a long time, leading to regional pollution by long-range transportation and enhancing the dangers to human health [9]. Most of the trace metals, such as Al, $\mathrm{Cr}, \mathrm{Mn}, \mathrm{Fe}, \mathrm{Ni}, \mathrm{Cu}, \mathrm{Zn}$ and $\mathrm{Pb}$, were internally mixed with secondary sulfate/organic particles [12]. Furthermore, the activity of $\mathrm{Cd}$ and As increased as the particle size reduced [13]. A great number of reports showed that heavy metals could be accumulated in haze, which meant that the haze particles could be effective to adsorb heavy metals. However, little attention was paid to use haze particles to remove pollutants from wastewater.

Very often, wastewater contained heavy metals at concentrations above local discharge limits. These metal ions were very toxic to living organisms, constituting an important threat for the health of plant and animals, especially for human [14]. It was well known that heavy metals could be easily accumulated in human tissues but were not degraded gradually [15]. Biological magnification through the food chain would be harmful to human health and ecological environmental safety [16]. Worst of all, heavy metals could disrupt normal cell and tissue function through disrupting membrane potentials and interacting with proteins or other biomolecules [17]. Cadmium was a carcinogenic toxicant that affected kidneys, disturbed bone metabolism and deformed reproductive tract as well as endocrine system [18]. Lead had adverse effects on erythropoiesis and haem biosynthesis, or even leading to some types of cancer [19]. Arsenic had serious impacts on the cardiovascular system and even resulted in the liver damage at high doses [20]. Hence, in order to protect human health and the environment, heavy metals must be removed from wastewater to bring their concentrations down to below the prescribed legal limit.

In the study, haze particles were successfully gathered for the removal of multiple heavy metals from aqueous solution. The main objectives are to: (1) gather and characterize haze, (2) investigate the removal efficiency of the co-existing heavy metals by haze, (3) test the kinetics of heavy metals removal by haze, and (4) evaluate the removal mechanism of co-existing heavy metals by haze particles.

\section{Materials and methods}

\subsection{Chemicals}

$\mathrm{K}_{2} \mathrm{Cr}_{2} \mathrm{O}_{7}, \mathrm{CdCl}_{2}$ and $\mathrm{PbCl}_{2}$ were provided by First Chemical Reagent Manufactory (Tianjin, China). All other chemicals were of analytical grade purity.

\subsection{Sample collection}

In the haze weather, the particles were collected from a $3 \mathrm{~m} \times 3 \mathrm{~m}$ kraft paper spreading out on the roof. The 
collected particles were passed through a 200 mesh screen. Then, the particles were gently ground using a quartz mortar for $2 \mathrm{~h}$. Finally, these ground particles were passed through a 1250 mesh screen. The simulated haze particles were successfully prepared and stored in a plastic bad for further use.

\subsection{Batch experiments}

Effects of different experimental conditions on the removal efficiency of heavy metals were studied as the following procedure. Haze partilces were added into the prepared wastewater at room temperature with mechanical agitation for $30 \mathrm{~h}$. Then, the wastewater was withdrawn using a $10 \mathrm{~mL}$ dispensable syringe and filtered through a $0.22 \mu \mathrm{m}$ filter for further analysis. All experiments were performed in duplicate.

\subsection{Characterization and analytical methods}

The concentrations of metals ions (K, $\mathrm{Ca}, \mathrm{Na}, \mathrm{Mg}, \mathrm{Zn}, \mathrm{Cr}$, $\mathrm{Cd}, \mathrm{Pb}, \mathrm{Cu}$ and $\mathrm{As}$ ) were measured using inductively coupled plasma-mass spectrometry (ICP-MS, Elan-9000, $\mathrm{PE})$. The concentrations of $\mathrm{NH}_{4}{ }^{+}, \mathrm{Cl}^{-}, \mathrm{NO}_{3}{ }^{-}$and $\mathrm{SO}_{4}{ }^{2-}$ were determined using an ion chromatograph (DIONEX, ICP-90, USA). The morphological analysis of haze particle was performed using a scanning electron microscope (SEM) (SEM, FEI Nova NanoSEM 230). The size of haze particles was analyzed using a particle size analyzer (Mastersizer 3000, Malvern). The specific surface area $\left(\mathrm{S}_{\mathrm{BET}}\right)$ of P-NZVI was measured with Brunauer-Emmett-Teller (BET) $\mathrm{N}_{2}$ method. The haze samples were used to the X-ray photoelectron spectroscope (XPS, PHI 5000 Versa Probe) analysis before and after reacting with wastewater, respectively.

\subsection{Haze particles reuse}

The potential to reuse haze particles for removing heavy metals from aqueous solution was also evaluated. $1.0 \mathrm{~g}$ of haze particles was added to $10 \mathrm{mg} / \mathrm{L}$ of heavy metals solution $(100 \mathrm{~mL})$ and the mixture was left at room temperature with slightly stirring. After each cycle, these particles were immersed in $30.0 \mathrm{mg} / \mathrm{L}$ of ethylenediaminetetraacetic acid disodium salt for 24 times to desorb heavy metals ions. Then, these particles were washed by deionized water for 3 times. The haze particles were used to remove heavy metals for 3 times in succession to test the efficacy of reuse under the identical experimental conditions.

\section{Results and discussion}

\subsection{SEM characterization and features analysis}

SEM images were used to qualitatively understand the morphology of haze particles and the result was shown in Figure 1. It can be seen (Fig. 1 (a)) that the structure of haze particles are complex, diverse and heterogeneous, such as spherical, flaky, strip-shaped, irregular, etc. At higher magnification, it was found that the surfaces of haze particles were rough and uneven (Fig. 1 (b)), which was favorable for accumulating heavy metals, leading to the removal of heavy metals from the atmosphere or wastewater.
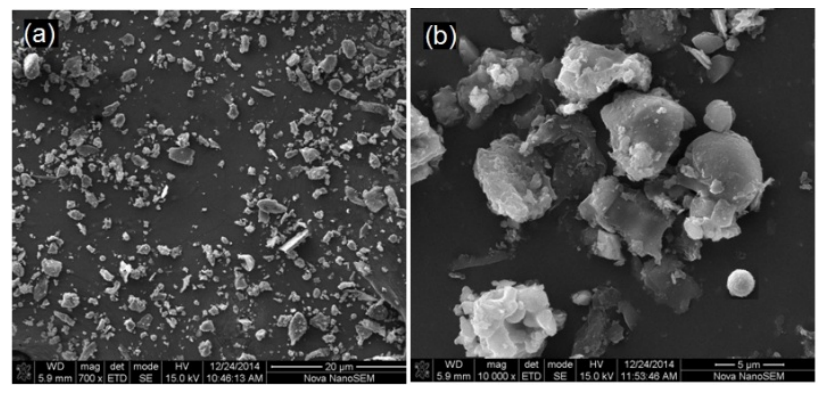

Figure 1 SEM image of haze particles (The scale bar represents (a) $20 \mu \mathrm{m}$ and (b) $5 \mu \mathrm{m}$ ).

Furthermore, the diameter of haze particles ranged from 0.1 to $20 \mu \mathrm{m}$, containing $55.6 \%$ of $\mathrm{PM}_{2.5}, 43.8 \%$ of $\mathrm{PM}_{10}$ and a very small amounts of coarse haze particles (Table 1). It could be seen from Table 2 that main compositions in haze particles were $\mathrm{NH}_{4}^{+}, \mathrm{K}^{+} \mathrm{Ca}^{2+}, \mathrm{Cl}^{-}$, $\mathrm{NO}_{3}{ }^{-}$and $\mathrm{SO}_{4}{ }^{2-}$, especially the anions were predominant. Other researchers found the similar phenomena [3]. Heavy metals were also found in haze particles and the concentrations were higher in $\mathrm{PM}_{2.5}$ than those in coarse haze particles (Table 2). The levels of As and Cd in haze particles exceeded the guidelines of World Health Organization [2]. Also, the $\mathrm{S}_{\mathrm{BET}}$ of haze particles was measured and the result was $18.6 \mathrm{~m}^{2} / \mathrm{g}$. As mentioned above, a result could be reasonably concluded that haze particles were suitable to being used to remove heavy metals from wastewater.

Table 1 The distribution of the size of haze particles.

\begin{tabular}{|c|c|c|c|}
\hline the size range $(\mu \mathrm{m})$ & $0.1-2.5$ & $2.5-10$ & $10-20$ \\
\hline the percentage $(\%)$ & 55.6 & 43.8 & 0.6 \\
\hline \multicolumn{4}{|c|}{$\begin{array}{c}\text { Table } 2 \text { Concentrations }\left(\mu \mathrm{g} / \mathrm{m}^{3}\right) \text { of main compositions in size- } \\
\text { resolved haze particles. }\end{array}$} \\
\hline $\begin{array}{l}\text { The size } \\
\text { main } \\
\text { compositions }\end{array}$ & $0.1-2.5$ & $2.5-10$ & $10-20$ \\
\hline $\mathrm{Na}^{+}$ & 0.5 & 0.8 & 0.9 \\
\hline $\mathrm{NH}_{4}^{+}$ & 10.2 & 6.6 & 5.8 \\
\hline $\mathrm{K}^{+}$ & 1.2 & 0.6 & 0.5 \\
\hline $\mathrm{Ca}^{2+}$ & 1.4 & 2.2 & 2.0 \\
\hline $\mathrm{Mg}^{2+}$ & 0.2 & 0.6 & 0.7 \\
\hline $\mathrm{Cl}^{-}$ & 4.8 & 1.6 & 1.7 \\
\hline $\mathrm{NO}_{3}^{-}$ & 26.0 & 17.2 & 18.0 \\
\hline $\mathrm{SO}_{4}{ }^{2-}$ & 32.0 & 16.5 & 17.8 \\
\hline $\mathrm{Zn}^{2+}$ & 0.06 & 0.02 & 0.01 \\
\hline $\mathrm{Pb}^{2+}$ & 0.4 & 0.1 & 0.02 \\
\hline $\mathrm{Cu}^{2+}$ & 0.06 & 0.03 & 0.01 \\
\hline $\mathrm{Cd}^{2+}$ & 0.06 & 0.04 & 0.02 \\
\hline $\mathrm{Cr}_{\text {total }}$ & 0.08 & 0.06 & 0.03 \\
\hline $\mathrm{As}^{3+}$ & 0.02 & 0.01 & 0.01 \\
\hline
\end{tabular}

$\mathrm{Cr}_{\text {total }}$ represented the total concentration of $\mathrm{Cr}$ ions. 


\subsection{Effect of the $\mathrm{pH}$ value}

According to the finding of Table 2, there were lots of cationic and anionic ions on the surface of haze particles, especially the anions predominated. Very often, a variation of $\mathrm{pH}$ values led to disturbing the acid-base balance of the solution [21]. The dominant forms of heavy metals in aqueous solution were also affected by $\mathrm{pH}$ [22]. Thus, $\mathrm{pH}$ values played an important part in the removal of heavy metals from wastewater by haze particles. The dependence of removal rates and $K_{o b s}$ on $\mathrm{pH}$ was investigated and the result was shown in Figure 2.

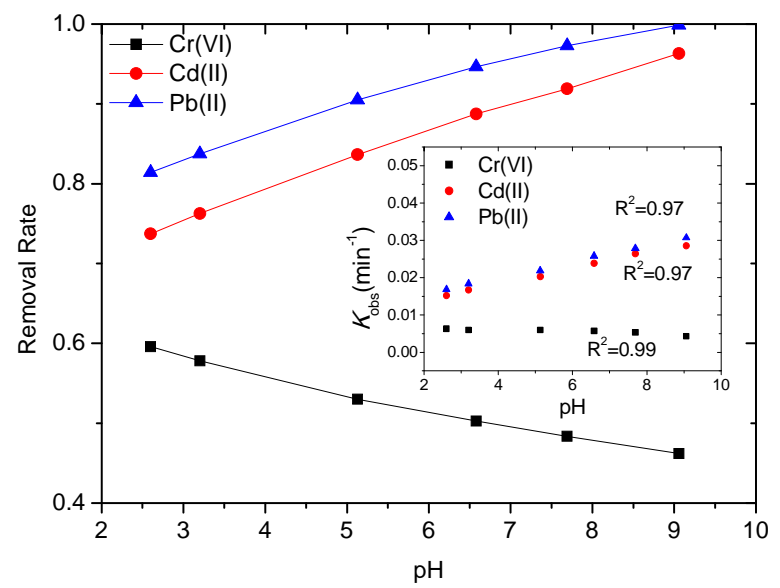

Figure 2 Effect of $\mathrm{pH}$ on removal rates and $K_{\text {obs }}$ by haze particles.

It was observed that with an increase of $\mathrm{pH}$ from 2.6 to 9.06, the removal rates and $\mathrm{K}_{\mathrm{obs}}$ of $\mathrm{Cr}$ (VI) decreased gradually while those of $\mathrm{Cd}$ (II) and $\mathrm{Pb}$ (II) increased (Fig. 2). At lower $\mathrm{pH}$ the haze particles were positively charged, while $\mathrm{Cr}$ (VI) existed mostly as an anion leading to the electrostatic attraction between $\mathrm{Cr}$ (VI) and the haze particles [23]. As a result, $\mathrm{Cr}$ (VI) removal rate decreased with an increase in $\mathrm{pH}$. However, with an increase in $\mathrm{pH}$ values, the number of negatively charged sites was improved, leading to the enhanced attraction force between heavy metals (Cd (II) and $\mathrm{Pb}$ (II)) and these particles surface. Therefore, the removal amount of $\mathrm{Cd}$ (II) and $\mathrm{Pb}$ (II) was increased as an increase in $\mathrm{pH}$.

Obviously, $\mathrm{K}_{\mathrm{obs}}$ of all heavy metals displayed a good linearity to $\mathrm{pH}$ values with correlation coefficients $\left(\mathrm{R}^{2}\right)$ more than 0.97. This indicated that the removal of $\mathrm{Cr}$ (VI), Cd (II) and Pb (II) by haze particles agreed well with the pseudo-first-order reaction kinetics. The similar phenomena had also been found in other systems using nanoscale iron, a- $\mathrm{Fe}_{2} \mathrm{O}_{3}$ nanoparticles and nanoscale iron supported on chitosan beads and pumice [24-27]. The results were consistent with the finding in Table 2.

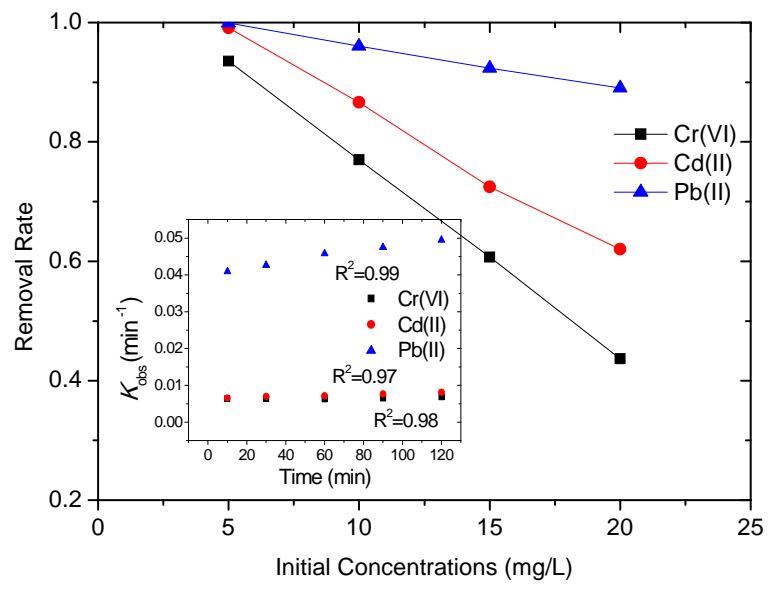

Figure 3 Effect of initial concentration of heavy metals on removal rates and $K_{o b s}$ by haze particles.

\subsection{Effect of initial concentration of heavy metals}

The effect of initial concentration of heavy metals on removal rates and $K_{o b s}$ was investigated and the result was shown in Figure 3. It can be observed that the removal rate and $\mathrm{K}_{\mathrm{obs}}$ of $\mathrm{Cr}$ (VI), $\mathrm{Cd}$ (II), and $\mathrm{Pb}$ (II) decreases with an increase of the initial concentrations of heavy metals (Fig. 3). According to a fixed adsorbent dose, the total available adsorption sites were limited [28]. Then, a decrease in removal rates and $\mathrm{K}_{\mathrm{obs}}$ of adsorbate was found corresponding to an increased initial adsorbate concentration (Figure 3). Similarly, the removal of $\mathrm{Cr}$ (VI), $\mathrm{Cd}$ (II) and $\mathrm{Pb}$ (II) by haze particles could be well described by pseudo-first-order kinetic model.

Furthermore, heavy metals are removed in the order $\mathrm{Pb}$ (II) $>\mathrm{Cd}$ (II) $>\mathrm{Cr}$ (VI) (Fig. 3). Due to the predominant anions on the surface of haze particles (Table 2), it was obvious that $\mathrm{Pb}$ (II) and $\mathrm{Cd}$ (II) were more easily integrated with haze particles than $\mathrm{Cr}$ (VI). The distribution characteristics of the electron cloud of $\mathrm{Pb}$ (II) might be suitable for the integration with haze particles leading to the most easily removal of $\mathrm{Pb}$ (II). The similar phenomena had been found using EGDE-CS-NZVI beads [27]. Previous researchers also found that the removal order was $\mathrm{Cu}$ (II) $>\mathrm{Pb}$ (II) $>\mathrm{Zn}$ (II) $>\mathrm{Cd}$ (II) using goethite [29]. However, heavy metals were removed in the order: $\mathrm{Pb}$ (II) $>\mathrm{Zn}$ (II) $>\mathrm{Cd}$ (II) $>\mathrm{Cr}$ (III) $>\mathrm{Cu}$ (II) by using eichhornia crassipes [30]. 


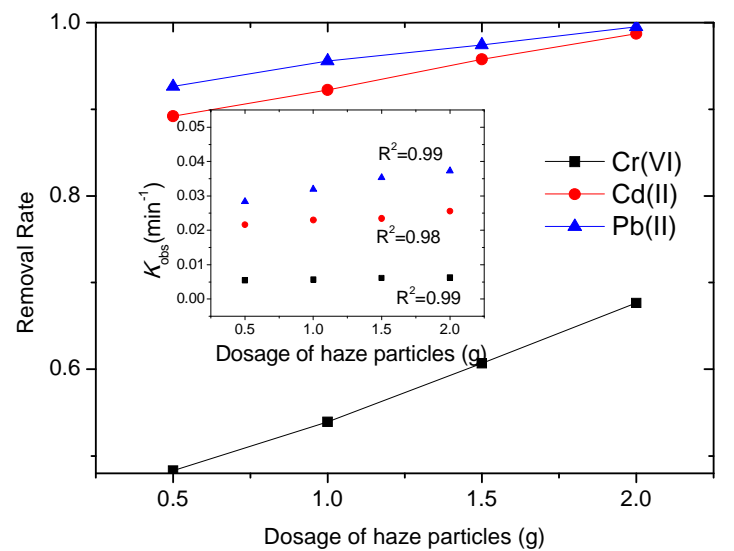

Figure 4 Effect of the dosage of haze particles on removal rates and $K_{o b s}$.

\subsection{Effect of the dosage of haze particles}

The effect of the dosage of haze particles on removal rates and $\mathrm{K}_{\mathrm{obs}}$ was conducted and the result was shown in Figure 4. Removal rates and $\mathrm{K}_{\mathrm{obs}}$ were increased with an increase in the dosage of haze particles (Figure 4). The increasing dosage of haze particles led to the increase in surface area and reactive sites of haze particles, which enhanced the rates and $\mathrm{K}_{\mathrm{obs}}$ of remediation. Also, $\mathrm{K}_{\mathrm{obs}}$ of all heavy metals displayed a good linearity to the dosage of haze particles with correlation coefficients $\left(\mathrm{R}^{2}\right)$ more than 0.98. The result was in agreement with the phenomenon discovered in other researches using nanoscale zero-valent iron $[24,25,31]$. Obviously, the results could be very useful for environmental engineers to control the dosage of haze particles for wastewater remediation applications.

\subsection{Effect of reaction temperature}

To assess the effect of reaction temperatures, batch experiments were conducted at $20,25,30$ and $35{ }^{\circ} \mathrm{C}$. The reaction temperatures had a negative effect on heavy metals removal and the rate constant decreased with an increase in the temperature from 20 to $35{ }^{\circ} \mathrm{C}$. The $\mathrm{K}_{\mathrm{obs}}$ of $\mathrm{Pb}$ (II) were $0.039,0.037,0.034$, and $0.032 \mathrm{~min}^{-1}$ at four temperatures, respectively (Fig. 5). The $\mathrm{K}_{\mathrm{obs}}$ of Cd (II) were $0.038,0.033,0.029$ and $0.025 \mathrm{~min}^{-1}$ at four temperatures, respectively (Fig. 5). However, the $\mathrm{K}_{\mathrm{obs}}$ of $\mathrm{Cr}$ (VI) were only $0.007,0.006,0.0058$ and $0.0054 \mathrm{~min}^{-1}$, respectively (Fig. 5). Rate constants of $\mathrm{Pb}$ (II) and Cd (II) were much higher than those of $\mathrm{Cr}$ (VI). The result was consistent with the findings in Figure 2. Haze particles would become a promising candidate for the removal of $\mathrm{Pb}$ (II) and $\mathrm{Cd}(\mathrm{II})$.

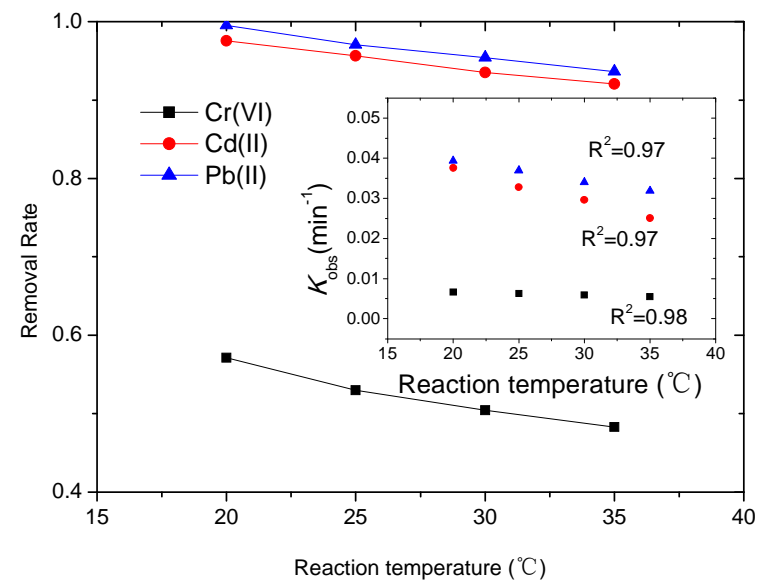

Figure 5 Effect of the reaction temperature on removal rates and $K_{o b s}$.

The apparent activation energy $\left(E_{a}\right)$ was obtained by plotting $\mathrm{K}_{\mathrm{obs}}$ against the temperature. Normally, an $\mathrm{E}_{\mathrm{a}}$ value in a range of $10-21 \mathrm{~kJ} / \mathrm{mol}$ was attributed to be a physically controlled reaction [32]. The $\mathrm{E}_{\mathrm{a}}$ of $\mathrm{Cr}(\mathrm{VI}), \mathrm{Pb}$ (II) and Cd (II) removal by haze particles was 11.3, 11.6 and $18.2 \mathrm{~kJ} / \mathrm{mol}$, respectively, indicating that it was a physical adsorption process. This could be useful to explain the phenomenon found in Figure 5. Increasing the reaction temperature resulted in an increase in vibration frequencies of heavy metals [33] and surface tension of haze particles $[34,35]$. As a result, the adsorption of heavy metals on haze particles became harder, leading to the decrease of removal rates and the rate constants of heavy metals.

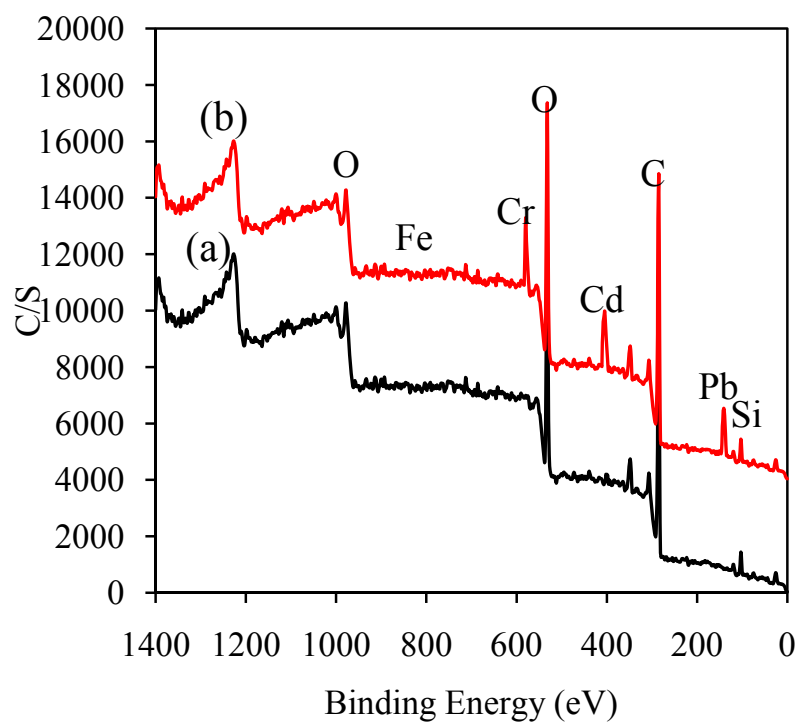

Figure 6 Typical wide scan XPS spectra for the EGDE-CSNZVI beads before and after heavy metals reduction: (a) before heavy metals reduction and (b) after heavy metals reduction.

\subsection{The removal mechanisms of heavy metals}

The results of XPS characterization of haze particles were shown in Fig. 6 and Fig. 7. New peaks at the binding energy (BE) of $588 \mathrm{eV}, 405 \mathrm{eV}$ and $138 \mathrm{eV}$ appeared 
after heavy metals adsorption (Figure 6), which was assigned to the photoelectron peak of $\mathrm{Cr}, \mathrm{Cd}$ and $\mathrm{Pb}$, respectively. The phenomenon indicated the uptake of $\mathrm{Cr}$, $\mathrm{Cd}$ and $\mathrm{Pb}$ on the surface of haze particles.
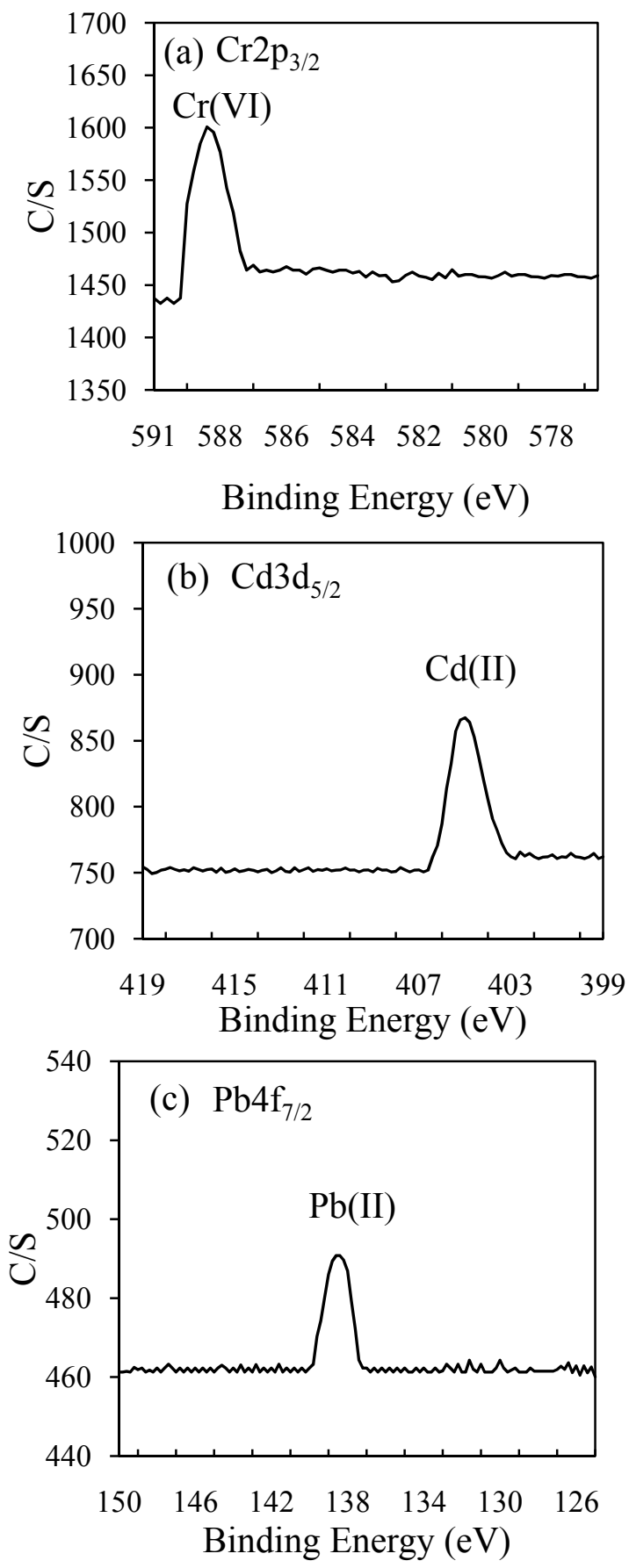

Figure 7 High-resolution XPS survey of (a) $\mathrm{Cr} 2 \mathrm{p}_{3 / 2}$, (b) $\mathrm{Cd} 3 \mathrm{~d}_{5 / 2}$ and (c) $\mathrm{Pb}_{4} \mathrm{f}_{7 / 2}$ of haze particles after reacting with wastewater for $1 \mathrm{~h}$. Initial concentration of Cr (VI): $50 \mathrm{mg} / \mathrm{L}, \mathrm{Cd}$ (II): 50 $\mathrm{mg} / \mathrm{L}$, and $\mathrm{Pb}$ (II): $50 \mathrm{mg} / \mathrm{L}$; haze particles: $1.0 \mathrm{~g}$; $\mathrm{pH}$ : 5.13; temperature: $20{ }^{\circ} \mathrm{C}$.

Detailed XPS surveys on the region of $\mathrm{Cr} 2 \mathrm{p}_{3 / 2}, \mathrm{Cd} 3 \mathrm{~d}_{5 / 2}$ and $\mathrm{Pb}_{4} \mathrm{f}_{7 / 2}$ are presented in Fig. 7. The photoelectron peak for $\mathrm{Cr} 2 \mathrm{p}_{3 / 2}$ centered at $588.6 \mathrm{eV}$ (Fig. 7(a)), which corresponded to $\mathrm{Cr}$ (VI) $[31,36]$. However, the peaks at 577.2 and $587.6 \mathrm{eV}$ assigned to $\mathrm{Cr}$ (III) [37] were not found in the study. The XPS results implied that the removal mechanism of $\mathrm{Cr}$ (VI) by haze particles was a physical adsorption process.

Photoelectron peaks centered at 405.2 and $411.6 \mathrm{eV}$, which was attributed to $\mathrm{Cd}$ (II) and $\mathrm{Cd}(0)$, respectively [36]. It was observed that the $\mathrm{Cd} 2 \mathrm{p}_{3 / 2}$ had the only one peak at $405.2 \mathrm{eV}$ (Fig. 7(b)), which meant that Cd (II) was mainly adsorbed on the haze particles surface without the reduction to $\mathrm{Cd}(0)$. Cd (II) was adsorbed on nanoscale iron surface by electrostatic interaction and specific surface bonding [37]. Other researchres reported that $\mathrm{Cd}$ (II) could be rapidly reduced and plated onto the iron surface $[38,39]$. Very often, the presence of both cationic and anionic species caused Cd (II) removal via precipitation of their minerals/salts [40]. However, without strong reducing capacity, Cd (II) removal by haze particles was a physical adsorption process.

Two peaks of the $\mathrm{Pb}_{4} \mathrm{f}_{7 / 2}$ at $136.0 \mathrm{eV}$ and $138.4 \mathrm{eV}$ was contributed to $\mathrm{Pb}(0)$ and $\mathrm{Pb}$ (II) [36], respectively. Similarly, as shown in Figure 7(c), the only one peak at $138.4 \mathrm{eV}$ was known as characteristic of $\mathrm{Pb}$ (II). Hence, it was reasonably proposed that the predominant adsorption was in effect for the removal of $\mathrm{Pb}$ (II), conforming the phonemenon previously observed in Figure 5.

\subsection{P-NZVI reuse}

The regeneration efficiency of haze particles was studied and the result was presented in Fig. 8. It was shown that a high removal efficiency of $\mathrm{Pb}$ (II) and $\mathrm{Cd}$ (II) still remained after recycling three times (Figure 8). The results suggested that haze particles were regenerated materials. The similar finding was reported using nanoscale iron supported on epichlorohydrin/chitosan beads for removal of $\mathrm{Cr}$ (VI) [41]. CS beads were regenerated by $1 \mathrm{~mol} / \mathrm{L}$ ammonium chloride solution found by Bansiwal et al. [42]. The metals-adsorbed CSpolyacrylamide beads were effectively desorbed or generated by $\mathrm{HClO}_{4}$ [43]. Due to the physical adsorption of heavy metals by haze particles, the desorption or regeneration could easily happen. However, the removal efficiency of $\mathrm{Cr}$ (VI) was undesirable (Figure 8). By now, it can be concluded that haze particles were regenerated materials, especially for cationic ions.

In term of the environmental pollution, haze particles were air pollutants and toxic wastes. However, according to our findings in the study, haze particles were an effective remediation material to remove heavy metals for the possible recovery.

\section{Conclusions}

The morphology of haze particles was heterogeneous and uneven with a mean diameter of $5.2 \mu \mathrm{m}$. The anions were predominant in main compositions of haze particles. As an increase of $\mathrm{pH}$ from 2.6 to 9.06, the removal rates and $\mathrm{K}_{\mathrm{obs}}$ of $\mathrm{Cr}$ (VI) decreased gradually while those of Cd (II) and $\mathrm{Pb}$ (II) increased. Removal rates and $\mathrm{K}_{\mathrm{obs}}$ were increased with an increase in the dosage of haze particles. The reaction temperatures and initial concentration of heavy metals had a negative effect on heavy metals 
removal. The removal of $\mathrm{Cr}$ (VI), $\mathrm{Cd}$ (II) and $\mathrm{Pb}$ (II) by haze particles could be well described by pseudo-firstorder kinetic model. Heavy metals were removed in the order $\mathrm{Pb}$ (II) $>\mathrm{Cd}$ (II) $>\mathrm{Cr}(\mathrm{VI})$. XPS results implied that the removal mechanism of $\mathrm{Cr}$ (VI), $\mathrm{Pb}$ (II) and $\mathrm{Cd}$ (II) by haze particles was a physical adsorption process, leading to an occurrence of the desorption or regeneration. Haze particles were regenerated materials, especially for cationic ions.

\section{Acknowledgments}

The authors thank Zhigang Zhang, Qian Wang and Yuntao Shang for their support with analyses. This work was financially supported by the Innovation Team Training Plan of the Tianjin Education Committee (TD12-5037), National Natural Science Foundation of China (21307090) and Tianjin Municipal Natural Science Foundation of China (14JCZDJC41000).

\section{References}

[1] B.H. Chen, H.D. Kan, R.J. Chen, S.H. Jiang, C.J. Hong, J. Air Waste Manage. 61, 1292 (2011).

[2] J. Duan, J. Tan, J. Hao, F. Chai, J. Environ. Sci. 26, 189 (2014).

[3] S. Tian, Y. Pan, Z. Liu, T. Wen, Y. Wang, J. Hazard. Mater. 279, 452 (2014).

[4] Y. Sun, G. Zhuang, A. Tang, Y. Wang, Z. An, Environ. Sci. Technol. 40, 3148 (2006).

[5] X. Zhuang, Y. Wang, H. He, J. Liu, X. Wang, T. Zhu, M. Ge, J. Zhou, G. Tang, J. Ma, J. Environ. Sci. 26, 2 (2014).

[6] E. Kang, J. Han, M. Lee, G. Lee, J.C. Kim, Atmos. Res. 127, 34 (2013).

[7] J. Duan, X. Bi, J. Tan, G. Sheng, J. Fu, Chemosphere 67, 614 (2007).

[8] J. Duan, J. Tan, S. Wang, J. Hao, F. Chai, J. Environ. Sci. 24, 87 (2012).

[9] J. Duan, J. Tan, Atmos. Environ. 74, 93 (2013).

[10]J. Tao, Z. Shen, C. Zhu, J. Yue, J. Cao, S. Liu, L. Zhu, R. Zhang, Atmos. Res. 118, 222 (2012).

[11]W.J. Li, L.Y. Shao, P.R. Buseck, Atmos. Chem. Phys. 10, 8119 (2010).

[12] S. Zhou, Q. Yuan, W. Li, Y. Lu, Y. Zhang, W. Wang, J. Environ. Sci. 26, 205 (2014).

[13] S.L. Lu, R. Zhang, Z.K. Yao, F. Yi, J.J. Ren, M.H. $\mathrm{Wu}, \mathrm{M}$. Feng, Q.Y. Wang, J. Environ. Sci.-China 24, 882 (2012).

[14] V. Mudgal, N. Madaan, A. Mudgal, R.B. Singh, S. Mishra, Open Nutraceut. J. 3, 94 (2010).

[15]A. Akcil, C. Erust, S. Ozdemiroglu, V. Fonti, F. Beolchini, J. Clean. Prod. 86, 24 (2015).

[16] S.P. Singh, Q.M. Lena, F.M.G. Tack, M.G. Verloo, J. Environ. Qual. 29, 1124 (2000).

[17]E.E. Santos, D.C. Lauria, C.L. Porto-Silveira, Sci. Total. Environ. 327, 69 (2004).

[18]X. Wu, T. Jin, Z. Wang, T. Ye, Q. Kong, G. Nordberg, J. Occup. Environ. Med. 43, 898 (2001).

[19] M.K. Siddiqui, S. Srivastava, P.K. Mehrotra, Biomed. Environ. Sci. 15, 298 (2002).
[20]T. Yoshida, H. Yamauchi, G. Fan-Sun, Toxicol. Appl. Pharm. 198, 243 (2004).

[21] V.L. Hood, R.L. Tannen, N. Engl. J. Med. 339, 819 (1998).

[22]D. Mohan, C.U. Pittman, J. Hazard. Mater. 137, 762 (2006).

[23] V.M. Boddu, K. Abburi, J.L. Talbott, E.D. Smith, Environ. Sci. Technol. 37, 4449 (2003).

[24] T. Liu, L. Zhao, D. Sun, X. Tan, J. Hazard. Mater. 184, 724 (2010).

[25] T. Liu, L. Zhao, X. Tan, S. Liu, J. Li, Y. Qi, G. Mao, Water Sci. Technol. 61, 2759 (2010).

[26] T. Liu, Z.L. Wang, Y. Sun, Chem. Eng. J. 263, 55 (2015).

[27]T. Liu, X. Yang, Z.L. Wang, X. Yan, Water Res. 47, 6691 (2013).

[28] T. Hiemstra, W.H. Van-Riemsdijk, J. Colloid Interface Sci. 210, 182 (1999).

[29] R.M. McKenzie, J. Soil Res. 18, 61 (1980).

[30] S.A. Shama, M.E. Moustafa, M.A. Gad, Portugaliae Electrochimica Acta 28, 125 (2010).

[31]B.A. Manning, J.R. Kiser, H. Kwon, S.R. Kanel, Environ. Sci. Technol. 41, 586 (2007).

[32]M.J. Pilling, P.W. Seakins, Reaction Kinetics, Oxford University Press, New York, 1995.

[33]E. Dendooven, W. J. Mortier, J. B. Uytterhoeven, J. Phys. Chem. 88, 1916 (1984).

[34] G. Halsey, J. Chem. Phys. 16, 931 (1948).

[35]M.E. Rivera-Ramos, A.J. Hernandez-Maldonado, Ind. Eng. Chem. Res. 46, 4991 (2007).

[36] S.M. Ponder, J.C. Darab, T.E. Mallouk, Environ. Sci. Technol. 34, 2564 (2000).

[37] X.Q. Li, J.S. Cao, W.X. Zhang, Ind. Eng. Chem. Res. 47, 2131 (2008).

[38] T.E. Shokes, G. Moller, Environ. Sci. Technol. 33, 282 (1999).

[39]R.T. Wilkin, M.S. McNeil, Chemosphere 53, 715 (2003).

[40]H. Genc-Fuhrman, P. Wu, Y.S. Zhou, A. Ledin, Desalination 226, 357 (2008).

[41] T. Liu, Z.L. Wang, L. Zhao, X. Yang, Chem. Eng. J. 189-190, 196 (2012).

[42]A. Bansiwal, D. Thakre, N. Labhshetwar, S. Meshram, S. Rayalu, Colloid. Surface. B 74, 216 (2009).

[43] N. Li, R. Bai, C. Liu, Langmuir 21, 11780 (2005). 